\title{
Production components of sunflower cultivars at different sowing times ${ }^{1}$
}

\author{
Ricardo Turchetto ${ }^{2}$, Lucas José Trombetta ${ }^{2}$, \\ Genesio Mario da Rosa², Gabriel Baraldi Volpi ${ }^{2}$, Sinara Barros ${ }^{2}$
}

\section{ABSTRACT}

The sowing time is of fundamental importance for achieving high yields in the sunflower (Helianthus annuus L.) crop, reducing risks and losses and maximizing the crop yield. This study aimed at evaluating the effect of the sowing time on morphological (plant height, number of leaves, stem diameter and head diameter) and production (1,000-achene weight and total yield) traits. The experiment was conducted in the $2017 / 2018$ and 2018/2019 crop seasons, using a randomized blocks design, in a $3 \times 2$ bi-factorial scheme, with three sowing times (October 20, November 19 and December 22) and two hybrids (BRS 321 and BRS 323). A negative interference from the environment and sowing time was observed for all the analyzed variables. The third sowing time (December 22), in both crop seasons, resulted in a drastic reduction in the morphological and production traits of the cultivars, with a $50 \%$ reduction in the yield of achenes.

KEYWORDS: Helianthus annuus L., sowing times, morphological traits.

\section{INTRODUCTION}

Sunflower (Helianthus annuus L.) belongs to the Asteraceae family, originally from Mexico, and is considered one of the four oilseeds of greatest interest, in terms of edible oil production, in the world (Castro et al. 2010). In addition to its feeding potential, it has also been attracting interest from the pharmaceutical, cosmetics, paint and cleaning industries (Jocic et al. 2015).

Since 2005, it has become an important crop for the biodiesel industry (Backes et al. 2008). Sunflower crude oil is considered an easily obtainable raw material, if compared to soybean, in addition to presenting high levels of vegetable oil (around 40-54 \%; Gazzola et al. 2012).

\section{RESUMO}

Componentes de produção de cultivares de girassol em diferentes épocas de semeadura

A época de semeadura é de fundamental importância para se alcançar altas produtividades na cultura do girassol (Helianthus annuи $\mathrm{L}$.), reduzindo riscos e perdas e maximizando a produtividade da cultura. Objetivou-se avaliar a interferência da época de semeadura nos caracteres morfológicos (altura de planta, número de folhas, diâmetro de colmo e de capítulo) e de produção (peso de mil aquênios e produtividade total). $\mathrm{O}$ experimento foi conduzido nos anos agrícolas de 2017/2018 e 2018/2019, utilizando-se delineamento de blocos casualizados, em esquema bifatorial $3 \times 2$, com três épocas de semeadura (20/10, 19/11 e 22/12) e dois híbridos (BRS 321 e BRS 323). Observou-se, para todas as variáveis analisadas, interferência negativa do ambiente e da época de semeadura. A terceira época de semeadura (22/12), em ambos os anos agrícolas, resultou em redução drástica nas características morfológicas e de produção das cultivares, com redução de 50 \% na produtividade de aquênios.

PALAVRAS-CHAVE: Helianthus annuus L., épocas de semeadura, características morfológicas.

In Brazil, the crop adapts to the most varied edaphoclimatic conditions, and can be cultivated from the Rio Grande do Sul to the Roraima state, above the Equator line. The high efficiency in using available water, resistance to water stress conditions and tolerance to high temperatures make sunflower a viable crop to income adding (Sheaffer et al. 1977, Castro et al. 1997). Depending on the temperature and water availability conditions, sunflower can be grown as a first or second crop, being little sensitive to the photoperiod, thus allowing its cultivation throughout the year in all grain producing regions in Brazil (Leite et al. 2007).

According to Conab (2020), the sunflower crop had a cultivation area of 62.1 thousand hectares, in the 2019/2020 crop season, with the national

\footnotetext{
${ }^{1}$ Received: Mar. 12, 2021. Accepted: May 26, 2021. Published: July 23, 2021. DOI: 10.1590/1983-40632021v5168137.

${ }^{2}$ Universidade Federal de Santa Maria, Frederico Westphalen, RS, Brasil. Email/ORCID: ricardoturchetto10@gmail.com/ 0000-0001-8634-5058; lucasjosetrombetta1@gmail.com/0000-0002-4430-2727; genesiomario@yahoo.com.br/0000-0003-1247-2286; gabrielbvolpi_189@hotmail.com/0000-0003-1757-6711; sinarabarros@yahoo.com.br/0000-0003-0466-4544.
} 
average yield reaching $1,581 \mathrm{~kg} \mathrm{ha}^{-1}$, being the Mato Grosso and Goiás states the largest producers. The best average yield of the producing regions was obtained in the Southeast region, reaching around $1,743 \mathrm{~kg} \mathrm{ha}^{-1}$.

Regarding the need for nutrients, boron and nitrogen are two elements that, when present in low concentrations, cause several nutritional problems, preventing the good development of the crop. Nitrogen is essential for plant growth and development, influencing the production and oil content of grains. On the other hand, boron is an essential element for plant growth and is linked to various physiological functions of the plant, as well as to the water extraction capacity, sugar translocation and nitrogen, phosphorus, carbohydrates and lipids metabolism (Al-amery et al. 2011).

One of the factors of fundamental importance for the good development of sunflower is the season when it is cultivated, which can influence the crop traits. For example, Cadorin et al. (2012) assessed crop traits in the northwest of the Rio Grande do Sul state and observed that the plant height and yield are influenced by the sowing time. Birck et al. (2017), evaluating the performance of eight sunflower cultivars in five seasons, in the Brazilian central region, concluded that the first growing season was the best for the evaluated productive and vegetative variables.

Characteristics such as plant height, head size, stem diameter and yield vary according to the genotype and edaphoclimatic conditions (Castiglioni et al. 1994), in addition to the sowing time (Mello et al. 2006).

This study aimed to evaluate the influence of the sowing time on the morphological and productive traits of two sunflower cultivars in two crop seasons.

\section{MATERIAL AND METHODS}

The experiment was conducted during the $2017 / 2018$ and 2018/2019 crop seasons, in an experimental area of the Universidade Federal de Santa Maria, in Frederico Westphalen, Rio Grande do Sul state, Brazil $\left(27^{\circ} 25^{\prime} \mathrm{S}, 53^{\circ} 43^{\prime} \mathrm{W}\right.$ and average altitude of $488 \mathrm{~m}$ ).

The soil is classified as a Red Dystrophic Latosol (Streck et al. 2008) and the climate is humid subtropical, type Cfa, according to the Köppen classification (Moreno 1961), with temperatures oscillating between 0 and $18^{\circ} \mathrm{C}$ in the coldest month and above $25{ }^{\circ} \mathrm{C}$ in the hottest month, and average annual rainfall of $2,100 \mathrm{~mm}$. The rainfall data during the experiment are described in Figure 1.

An experimental randomized blocks design, in a $3 \times 2$ bi-factorial scheme, was used, with three sowing times and two cultivars, with four replications. The sunflower cultivars were BRS 321, with early cycle, resistance to downy mildew and plant height of 1.65-1.85 m; and BRS 323, with early cycle, resistance to downy mildew and plant height of 1.66-190 m, developed by Embrapa.

For weed management, desiccation was carried out30 days before sowing, with broad-spectrum herbicide [N-diammonium salt (phosphonomethyl) glycine]. An insecticide (lambda-cyhalothrin + thiamethoxam) was also used for weed pests management.

The sowing density was 45,000 final plants ha-1, for the three sowing times and both cultivars. Each sample unit was $4 \mathrm{~m}$ wide ( 5 cultivation rows spaced $0.70 \mathrm{~m}$ from each other) and $5 \mathrm{~m}$ in length, being composed of 90 plants in total; however, only 30 of these plants comprised the useful area of the plot. The

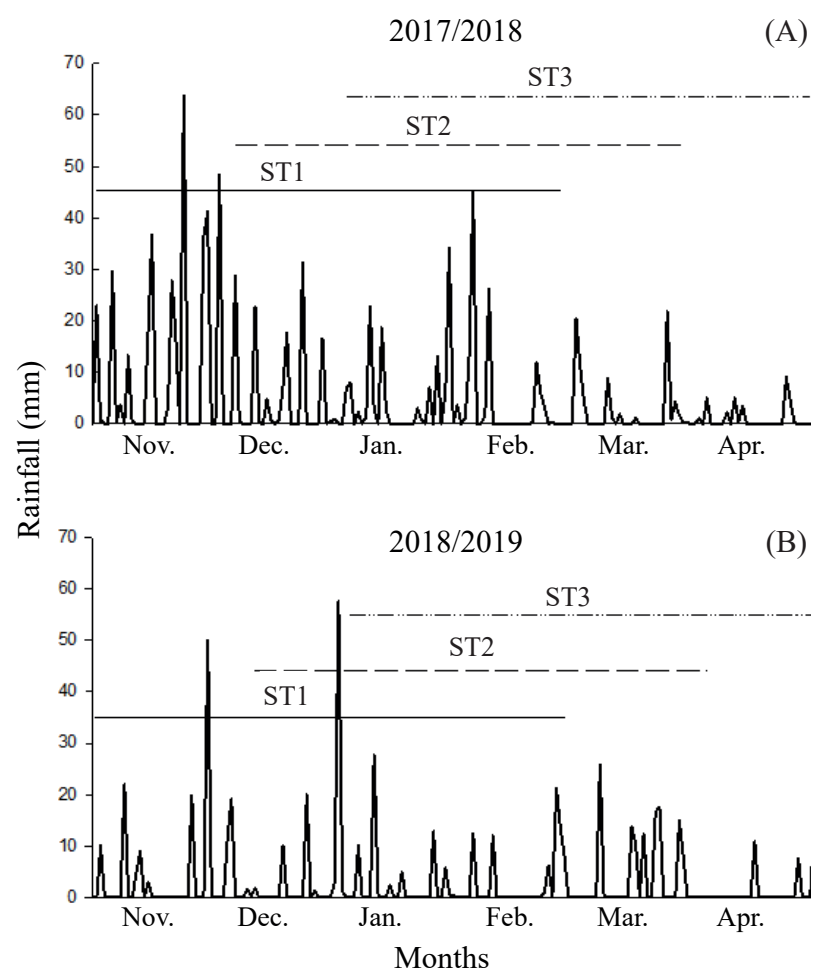

Figure 1. Rainfall data referring to two sunflower crop seasons, in Frederico Westphalen, Rio Grande do Sul state, Brazil. Source: Brasil (2020). ST1: sowing time 1 (October 20); ST2: sowing time 2 (November 19); ST3: sowing time 3 (December 22). 
sowing was staggered on October 20, November 19 and December 22, for both crop seasons.

The production technology adopted in the crop followed indications for sunflower cultivation under rainfed management in the Rio Grande do Sul state (Leite et al. 2007). Thus, in the period prior to the sowing of the sunflower crop, a soil sampling was carried out $\left(\mathrm{pH}=5.2 ; \mathrm{K}=158.8 \mathrm{mg} \mathrm{L}^{-1} ; \mathrm{P}=\right.$ $12.8 \mathrm{mg} \mathrm{L}^{-1} ; \mathrm{B}=0.14 \mathrm{mg} \mathrm{L}^{-1}$; organic matter $=1.8 \%$; clay $=71 \%$ ) and, then, soil correction was done (CQFS-RS/SC 2016).

Given the crop's high need of the micronutrient $\mathrm{B}$, borax was applied along the drying area, dissolved in water $\left(3 \mathrm{~kg} \mathrm{ha}^{-1}\right)$.

Within the useful area of each plot, 6 random plants were collected and phenologically evaluated for plant height [performed in the R5.5 stage (full blooming), measured from the ground level to the head insertion section, in $\mathrm{cm}$ ], number of leaves (performed at the end of the crop cycle by counting the number of leaves from the base to the apex of the plant), stem diameter (measured at the full blooming stage with a pachymeter, $5 \mathrm{~cm}$ above the ground level, with results expressed in $\mathrm{cm}$ ); fresh mass (evaluated at the harvest time, with stems and leaves ground separately for each plant, then packed in paper bags and weighed in an analytical scale, with results expressed in $\mathrm{kg}$ ) and dry mass (obtained after the fresh mass had been placed in an oven at a controlled temperature of about $65^{\circ} \mathrm{C}$, until it reached constant weight, being weighted in an analytical scale, with results expressed in $\mathrm{kg}$ ).

In order to determine yield, the following parameters were evaluated: 1,000 -achene weight (determined by collecting the achenes from the six plants used in the morphological evaluations and weighing in an analytical scale, standardizing the sample's humidity at $10 \%$, with results expressed in $\mathrm{kg}$ ) and achenes yield (corresponding to the weighing of all achenes produced inside the working area of each plot, considering the six plants that were randomly collected and this value extrapolated to an area of $1 \mathrm{ha}$, correcting the humidity to the standard of $10 \%$, with results expressed in $\mathrm{tha}^{-1}$ ).

An analysis of variance was performed for all data, following the chi-square test and observing the normality of the data. The variables that showed interaction among the factors had their averages compared by the Scott-Knott test, at $5 \%$ of probability. All the analyses were considered to be less than $0.05 \%$ of probability and were performed using the Sisvar statistical software (Ferreira 2014).

\section{RESULTS AND DISCUSSION}

The rainfall regime in the study region (Figure 1) was similar for both crop seasons. In the first one (Figure 1A), accumulated regimes of 734 and $575 \mathrm{~mm}$ of rain were respectively observed for October 20 and November 19. However, for December 22, there was an average reduction of $52.4 \%$ in the pluviometric index, when compared to the first sowing time, totaling $349 \mathrm{~mm}$. For the second crop season, October 20 and November 19 accumulated 571 and $479 \mathrm{~mm}$ of rain, respectively; however, for December 22, there was a reduction of $41.3 \%$, when compared to the first sowing time, accumulating $335 \mathrm{~mm}$.

For the individual analysis of the parameters evaluated in the two crop seasons, the coefficients of variation for the traits ranged from 3.91 to $18.14 \%$, being these of low magnitude (Gomes 1986). With that, the experimental planning and the statistical design were efficient to eliminate heterogeneities that existed in the experimental area.

For stem diameter, number of leaves, fresh and dry mass and 1,000-achene weight, there was a significant interaction between cultivars and seasons.

Regarding the stem diameter (Table 1), it was observed that the cultivar BRS 323 presented mean values above those of the BRS 321 in the 2017/2018 crop season for the three sowing times, but mean values below those of BRS 321 in the 2018/2019 crop season for the third sowing time. When comparing the sowing times, it was observed that, at the third sowing time, there was a reduction in stem diameter for both cultivars, regardless of the crop season. This fact corroborates Birck et al. (2017), who evaluated the performance of eight sunflower cultivars in different sowing times, in central Brazil, and found lower stem diameter values $(22.54 \mathrm{~mm})$ in late sowing.

For number of leaves (Table 1), BRS 321 was superior in the first crop season, when compared to BRS 321, with an average of 33 leaves. However, in the second crop season, there was no difference between the cultivars. When the sowing times were compared, a reduction in the number of leaves was observed for both crop seasons, mainly in the third sowing time, due to the decrease in rainfall during this period (Figure 1). 
Table 1. Comparison of averages between cultivars and sowing times for stem diameter and number of leaves, in two crop seasons.

\begin{tabular}{|c|c|c|c|c|c|c|c|c|}
\hline \multirow{3}{*}{ Sowing time } & \multicolumn{4}{|c|}{$2017 / 2018$} & \multicolumn{4}{|c|}{$2018 / 2019$} \\
\hline & \multicolumn{2}{|c|}{ - Stem diameter —_ } & \multicolumn{2}{|c|}{ — Number of leaves _- } & \multicolumn{4}{|c|}{ Stem diameter —— Number of leaves — } \\
\hline & BRS 321 & BRS 323 & BRS 321 & BRS 323 & BRS 321 & BRS 323 & BRS 321 & BRS 323 \\
\hline October 20 & $25.995 \mathrm{Bb}^{*}$ & $29.347 \mathrm{Aa}$ & $34.792 \mathrm{Aa}$ & $32.417 \mathrm{Ba}$ & $25.268 \mathrm{Aa}$ & $26.613 \mathrm{Aa}$ & $26.875 \mathrm{Aa}$ & $26.458 \mathrm{Aa}$ \\
\hline November 19 & $30.498 \mathrm{Aa}$ & $30.905 \mathrm{Aa}$ & $35.792 \mathrm{Aa}$ & $30.875 \mathrm{Bb}$ & $23.274 \mathrm{Ab}$ & $23.824 \mathrm{Ab}$ & $23.292 \mathrm{Ab}$ & $22.500 \mathrm{Ab}$ \\
\hline December 22 & $23.664 \mathrm{Ac}$ & $23.670 \mathrm{Ab}$ & $28.625 \mathrm{Ab}$ & $29.083 \mathrm{Ac}$ & $22.105 \mathrm{Ab}$ & $20.061 \mathrm{Bc}$ & $18.458 \mathrm{Ac}$ & $18.250 \mathrm{Ac}$ \\
\hline$\overline{\mathrm{CV}(\%)}$ & \multicolumn{2}{|c|}{11.80} & \multicolumn{2}{|c|}{7.76} & \multicolumn{2}{|c|}{12.28} & \multicolumn{2}{|c|}{9.13} \\
\hline
\end{tabular}

* Averages followed by the same uppercase letter in the column and lowercase letter in the row do not differ by the Scott-Knott test at $5 \%$ of probability.

According to Taiz \& Zeiger (2017), leaves play an important role, mostly because they are one of the major organs by which plants normally compete for sunlight, absorbing it and influencing the photosynthetic rates and growth. This statement is in line with what was observed in the present study, since the smaller number of leaves obtained in the third sowing time (December 22) may have influenced the other variables analyzed, which also had a reduction in their values at that sowing time.

For the 1,000-achene weight (Table 2), it was observed that the cultivar BRS 321 was superior to BRS 323 in the two crop seasons, reaching an average of $84 \mathrm{~g}$ in the second one. Capone et al. (2012), evaluating different sowing times in the south of the

Table 2. Comparison of averages between cultivars and sowing times for 1,000-achene weight, in two crop seasons.

\begin{tabular}{|c|c|c|c|c|}
\hline \multirow[t]{2}{*}{ Sowing time } & \multicolumn{4}{|c|}{$\begin{array}{c}-2017 / 2018-\frac{2018 / 2019}{-}-1,000 \text {-achene weight }(\mathrm{g})\end{array}$} \\
\hline & BRS 321 & BRS 323 & BRS 321 & BRS 323 \\
\hline October 20 & $75 \mathrm{Ab}^{*}$ & $74 \mathrm{Aa}$ & $100 \mathrm{Aa}$ & $86 \mathrm{Ba}$ \\
\hline November 19 & $86 \mathrm{Aa}$ & $79 \mathrm{Aa}$ & $94 \mathrm{Aa}$ & $83 \mathrm{Ba}$ \\
\hline December 22 & $54 \mathrm{Ac}$ & $44 \mathrm{Bb}$ & $58 \mathrm{Ab}$ & $58 \mathrm{Ab}$ \\
\hline
\end{tabular}

* Averages followed by the same uppercase letter in the column and lowercase letter in the row do not differ by the Scott-Knott test at $5 \%$ of probability.
Tocantins state, correlated the 1,000 -achene weight to the head diameter, associating that larger heads have a longer time for grain filling, results that corroborate those found in the present study, where the cultivar BRS 321, which showed a higher 1,000-achene weight, also showed a greater head diameter. When comparing the sowing dates, December 22 showed lower results than October 20 and November 19 for both the crop seasons, with an average of $51 \mathrm{~g}$. A similar result was found by Cadorin et al. (2012), who observed that, at the later time evaluated, which presented water restrictions, there was a reduction in the 1,000-achene weight (average of $53.82 \mathrm{~g}$ ), as water deficit restricts the filling of achenes arising from a lower reserve accumulation in the leaves, stem and head.

By analyzing the plant height (Table 3 ), it is noted that the cultivar BRS 321 had a lower height in both crop seasons, what is a relevant characteristic, as it reduces the risk of lodging. When comparing the sowing times, December 22 showed a greater water restriction (Figure 1), causing a significant reduction in plant height for both crop seasons, as water limitations in the soil provide reductions in plant height for sunflower cultivation (Castro \& Farias 2005, Cadorin et al. 2012).

Table 3. Comparison of averages of cultivars and sowing times for plant height (PH), yield and head diameter (HD), in two crop seasons.

\begin{tabular}{|c|c|c|c|c|c|c|}
\hline \multirow{2}{*}{ Cultivar } & \multicolumn{3}{|c|}{$2017 / 2018$} & \multicolumn{3}{|c|}{$2018 / 2019$} \\
\hline & $\mathrm{PH}(\mathrm{m})$ & Yield $\left(\mathrm{t} \mathrm{ha}^{-1}\right)$ & $\mathrm{HD}(\mathrm{cm})$ & PH (m) & Yield $\left(\mathrm{t} \mathrm{ha}^{-1}\right)$ & $\mathrm{HD}(\mathrm{cm})$ \\
\hline BRS 321 & $1.787 \mathrm{~B}^{*}$ & $3.027 \mathrm{~A}$ & $22.847 \mathrm{~A}$ & $1.685 \mathrm{~B}$ & $1.951 \mathrm{~A}$ & $22.875 \mathrm{~A}$ \\
\hline BRS 323 & $1.811 \mathrm{~A}$ & $2.847 \mathrm{~A}$ & $21.347 \mathrm{~B}$ & $1.792 \mathrm{~A}$ & $2.044 \mathrm{~A}$ & $22.403 \mathrm{~A}$ \\
\hline \multicolumn{7}{|l|}{ Sowing time } \\
\hline October 20 & $1.903 \mathrm{~A}$ & $3.192 \mathrm{~A}$ & $22.583 \mathrm{~B}$ & $1.951 \mathrm{~A}$ & $2.897 \mathrm{~A}$ & $26.666 \mathrm{~A}$ \\
\hline November 19 & $1.902 \mathrm{~A}$ & $3.515 \mathrm{~A}$ & $23.937 \mathrm{~A}$ & $1.768 \mathrm{~A}$ & $1.953 \mathrm{~B}$ & $22.896 \mathrm{~B}$ \\
\hline December 22 & $1.593 \mathrm{~B}$ & $2.104 \mathrm{~B}$ & $19.770 \mathrm{C}$ & $1.547 \mathrm{~B}$ & $1.142 \mathrm{C}$ & $18.354 \mathrm{C}$ \\
\hline CV (\%) & 3.910 & 18.140 & 14.100 & 8.560 & 16.140 & 12.270 \\
\hline
\end{tabular}


For yield (Table 3), there was no significant difference between the cultivars for the two crop seasons. On the other hand, when comparing the sowing times, there was a significant reduction for December 22. These results corroborate those found by Ribeiro et al. (2015), evaluating the productive parameters of sunflower in different sowing times, where they found a higher yield at the early sowing time, because, in October and November, more favorable climatic conditions were observed for the crop development, and also due to the high temperatures and a reduction in the rainfall index at the later sowing time.

Also according to Ungaro et al. (2000), Porto et al. (2007) and Backes et al. (2008), when there is procrastination of the sowing time, a reduction in yield is observed. For the experiment in question, there was an average reduction of $50 \%$ in yield with delayed sowing, due to the reduction in the pluviometric index. The delay in sowing may lead to decreases of up to $92 \%$ in sunflower yield, and its productive potential is compromised by the reduction of the rainfall index and the higher incidence of pests and diseases (Afférri et al. 2008, Santos et al. 2012).

For head diameter (Table 3), it was observed that, in the first crop season, BRS 321 showed to be superior to BRS 323; however, in the second crop season, both behaved similarly. Concerning the sowing times, December 22 proved to be inferior, in relation to the others. The sunflower head diameter is an important variable, as it provides a greater number and size of achenes, and this variable may be influenced by the pluviometric index, temperature and mainly by the spacing between rows and plant density per row at sowing, factors that influence the competition among sunflower plants, changing the physiological aspects of the crop (Souza et al. 2015).

According to Castro \& Farias (2005), the head diameter is an intrinsic characteristic of each variety; however, as observed in this study, this variable, even if being an intrinsic characteristic of the genotype, suffered a strong influence of the sowing time, since the December 22 sowing time had an average reduction of $25 \%$ for head diameter, in both crop seasons.

\section{CONCLUSIONS}

1. Plant height and head diameter are influenced by sowing times and growing environment;
2. Head diameter, being a productive variable of the sunflower crop, decreased about $25 \%$ in the third sowing time (December 22), causing an average reduction of $50 \%$ in the final yield of the crop, in the two crop seasons;

3. The sunflower crop yield is influenced by weather conditions and sowing time. In the the first (October 20 ) and second (November 19) sowing times, the head and stem diameter, number of leaves and yield were higher than for the third (December 22) sowing time, for both the BRS 321 and BRS 323 cultivars. For 1,000-achene weight and plant height, the first and second sowing times also stood out, in relation to the third one; however, the 1,000-achene weight was higher for BRS 321 than for BRS 323 and the plant height was higher for BRS 323 than for BRS 321, for both crop seasons.

\section{REFERENCES}

AFFÉRRI, F. S.; BRITO, L. R.; SIEBENEICHLER, S. C.; PELUZIO, J. M.; NASCIMENTO, L. C. do; OLIVEIRA, T. C. de. Avaliação de cultivares de girassol, em diferentes épocas de semeadura, no sul do estado do Tocantins, safra 2005/2006. Ciência \& Desenvolvimento, v. 4, n. 7, p. 79-87, 2008.

AL-AMERY, M. M.; HAMZA, J. H.; FULLER, M. P. Effect of boron foliar application on reproductive growth of sunflower (Helianthus annuus L.). International Journal of Agronomy, v. 2011, n. 1, p. 1-6, 2011.

BACKES, R. L.; SOUZA, A. M. de; BALBINOT JUNIOR, A. A.; GALLOTTI, G. J. M.; BAVARESCO, A. Desempenho de cultivares de girassol em duas épocas de plantio de safrinha no planalto norte catarinense. Scientia Agraria, v. 9, n. 1, p. 41-48, 2008.

BIRCK, M.; DALCHIAVON, F. C.; STASIAK, D.; IOCCA, A. F. S.; HIOLANDA, R.; CARVALHO, C. G. P. Performance of sunflower cultivars at different seeding periods in central Brazil. Ciência e Agrotecnologia, v. 41, n. 1, p. 42-51, 2017.

BRASIL. Instituto Nacional de Meteorologia. Banco de dados meteorológicos. 2020. Available at: https://portal. inmet.gov.br/. Access on: 25 Sep. 2020.

CADORIN, A. M. R.; SOUZA, V. Q. de; MANFRON, P. A.; CARON, B. O.; MEDEIROS, S. L. P. Características de plantas de girassol, em função da época de semeadura, na região noroeste do Rio Grande do Sul. Ciência Rural, v. 42 , n. 10, p. 1738-1743, 2012.

CAPONE, A.; BARROS, H. B.; SANTOS, E. R. dos; CASTRO, E. F. de; SANTOS, A. F. dos; FIDELIS, R. R. 
Efeito de épocas de semeadura de girassol na safrinha, em sucessão à soja no Cerrado Tocantinense. Revista Ceres, v. 59, n. 1, p. 102-109, 2012.

CASTIGLIONI, V. B. R.; BALLA, A.; CASTRO, C. de; SILVEIRA, J. M. Fases de desenvolvimento da planta do girassol. Londrina: Embrapa-CNPSo, 1994.

CASTRO, C.; CASTIGLIONI, V. B. R.; BALLA, A.; LEITE, R. M. V. B. de; KARAM, D.; MELLO, H. C.; GUEDES, L. C. A.; FARIAS, J. R. B. A cultura do girassol. Londrina: Embrapa Soja, 1997.

CASTRO, C.; FARIAS, J. R. B. Ecofisiologia do girassol. In: LEITE, R. M. V. B. C.; BRIGHENTI, A. M.; CASTRO, C. (ed.). Girassol no Brasil. Londrina: Embrapa Soja, 2005. p. 163-218.

CASTRO, C. de; CASTRO, C. N.; SOUSA, T. C. R.; LAZZAROTTO, J. J. Sistema produtivo de girassol para a produção de biodiesel. In: CASTRO, A. M. G. de; LIMA, S. M. V.; SILVA, J. F. V. Complexo agroindustrial de biodiesel no Brasil: competitividade das cadeias produtivas de matérias-primas. Brasília, DF: Embrapa Agroenergia, 2010. p. 376-420

COMISSÃO DE QUÍMICA E FERTILIDADE DO SOLO DO RIO GRANDE DO SUL E DE SANTA CATARINA (CQFS-RS/SC). Manual de calagem e adubação para os estados do Rio Grande do Sul e de Santa Catarina. Porto Alegre: SBCS, 2016.

COMPANHIA NACIONAL DE ABASTECIMENTO (Conab). Acompanhamento da safra brasileira de grãos: safra 2019/20. Brasília, DF: Conab, 2020.

FERREIRA, D. F. Sisvar: a computer statistical analysis system. Ciência e Agrotecnologia, v. 35, n. 6, p. 10391042, 2014.

GAZZOLA, A.; FERREIRA JUNIOR, C. T. G.; CUNHA, D. A.; BORTOLINI, E.; PAIAO, G. D.; PRIMIANO, I. V. ; PESTANA, J.; D'ANDRÉA, M. S. C.; OLIVEIRA, M. S. A cultura do girassol. Piracicaba: ESALQ, 2012.

GOMES, F. P. Curso de estatística experimental. São Paulo: Nobel, 1986.

JOCIC, S.; MILADINOVIC, D.; KAYA, Y. Breeding and genetics of sunflower. In: FORCE, E. M.; DUNFORD, N. T.; SALAS, J. J. (ed.). Sunflower: chemistry, production, processing, and utilization. Urbana: AOCS, 2015.

LEITE, R. M. V. B. de C.; CASTRO, C. de; BRIGHENTI, A. M.; OLIVEIRA, F. A. de; CARVALHO, C. G. P. de.; OLIVEIRA, A. C. B. de. Indicações para o cultivo de girassol nos estados do Rio Grande do Sul, Paraná, Mato Grosso do Sul, Mato Grosso, Goiás e Roraima. Londrina: Embrapa Soja, 2007. (Comunicado técnico, 78).

MELLO, R.; NÖRNBERG, J. L.; RESTLE, J.; NEUMANN, M.; QUEIROZ, A. C. de; COSTA, P. B.; MAGALHÃES, A. L. R.; DAVID, D. B. de. Características fenológicas, produtivas e qualitativas de girassol em diferentes épocas de semeadura para produção de silagem. Revista Brasileira de Zootecnia, v. 35, n. 3, p. 672-682, 2006.

MORENO, J. A. Clima do Rio Grande do Sul. Boletim Geográfico do Rio Grande do Sul, n. 11, p. 49-83, 1961.

PORTO, W. S.; CARVALHO, C. G. P. de; PINTO, R. J. B. Adaptabilidade e estabilidade como critérios para seleção de genótipos de girassol. Pesquisa Agropecuária Brasileira, v. 42, n. 4, p. 491-499, 2007.

RIBEIRO, J.; ANDREATTA, L. G. S.; GRISS, M. A.; LAJUS, C. R.; SORDI, A.; CERICATO, A.; LUZ, G. L. da. Determinação dos componentes de rendimento da cultura do girassol (Helianthus annuus L.) em épocas de semeadura na região extremo-oeste catarinense. Unoesc \& Ciência-ACET, v. 6, n. 1, p. 25-30, 2015.

SANTOS, E. R. dos; BARROS, H. B.; CAPONE, A.; FERRAZ, E. de C.; FIDELIS, R. R. Efeito de épocas de semeadura sobre cultivares de girassol, no sul do estado do Tocantins. Revista Ciência Agronômica, v. 43, n. 1, p. 199-206, 2012.

SHEAFFER, C. C.; MCNEMAR, J. H.; CLARK, N. A. Potential of sunflowers for silage in double-cropping systems following small grains. Agronomy Journal, v. 69, n. 4, p. 543-546, 1977.

SOUZA, F. R. de; SILVA, I. M. da; PELLIN, D. M. P.; BERGAMIN, A. C.; SILVA, R. P. da. Características agronômicas do cultivo de girassol consorciado com Brachiaria ruziziensis. Revista Ciência Agronômica, v. 46, n. 1, p. 110-116, 2015.

STRECK, E. V.; KÄMPF, N.; DALMOLIN, R. S. D.; KLAMT, E.; NASCIMENTO, P. C. do; SCHNEIDER, P.; GIASSON, E.; PINTO, L. F. S. Solos do Rio Grande do Sul. Porto Alegre: Ed. UFRGS/Emater-RS, 2008.

TAIZ, L.; ZEIGER, E. Fisiologia e desenvolvimento vegetal. 6. ed. Porto Alegre: Artmed, 2017.

UNGARO, M. R. G.; NOGUEIRA, S. S.; NAGAI, V. Parâmetros fisiológicos, produção de aquênios e fitomassa de girassol em diferentes épocas de cultivo. Bragantia, v. 59 , n. 2 , p. $205-211,2000$. 